\title{
THE GENUS MILIUSA IN THE AUSTRO-MALESIAN AREA (ANNONACEAE), A RECTIFICATION
}

\author{
J.B. MOLS \& P.J.A. KESSLER \\ Nationaal Herbarium Nederland, Universiteit Leiden branch, \\ P.O. Box 9514, 2300 RA Leiden, The Netherlands \\ e-mail:mols@nhn.leidenuniv.nl,kessler@nhn.leidenuniv.nl
}

SUMMARY

Confusion concerning the validation of Miliusa vidalii J. Sinclair is rectified.

Key words: Annonaceae, Miliusa, Miliusa vidalii, Australia, Flora Malesiana.

When we published the revision of the genus Miliusa in the Flora Malesiana area and Australia, nomenclatorial confusion concerning the species Miliusa vidalii has arisen (Mols \& Keßler, 2003: 455). During the process of publishing the sentences "Published without Latin description. No validation has been found." were separated from the true nomenclatorial section. Therefore it appears that this statement refers to Miliusa vidalii. In truth the sentences refer to the synonym Polyalthia pacifica Elmer. As this species was published in 1939 without a Latin description, which is required for all names published after 1 January 1935, this name is illegitimate. Miliusa vidalii, on the contrary, was properly published.

Miliusa vidalii J. Sinclair (1955) 378. - Saccopetalum longipes S. Vidal (1886) 43 non M. longipes

King. - Type: Vidal 15 (lecto K), Philippines, Luzon, Pr. Bataan, Bagac, fr.

Polyalthia pacifica Elmer (1939) 3690, nom. illeg. - Type: Elmer 17357 (holo A; iso BO, L, P),

Philippines, Luzon, Prov. Sorsogon, Irosin, Mt Bulusan, September 1916, fl. Published without

Latin description. No validation could be found.

\section{ACKNOWLEDGEMENTS}

We are grateful to Dr. J.D. Kruijer for pointing out the error in the publication.

\section{REFERENCES}

Elmer, A.D.E. 1939. Miscellaneous new species. Leafl. Phillipp. Bot. 10: 3684-3692.

Mols, J.B. \& P.J.A. Keßler. 2003. The genus Miliusa (Annonaceae) in the Austro-Malesian area.

Blumea 48: 421-462.

Sinclair, J. 1955. A revision of the Malayan Annonaceae. Gard. Bull. Straits Settlem. 14: 149-516. Vidal y Soler, S. 1886. Revisíon de plantas vasculares filipinas. M. Perez Hijo, Manila. 